\title{
The Effect of Covid-19 on SMEs and Entrepreneurial Resilience in Ethiopia. A Case of Nekemte Town
}

\author{
Dugasa Rafisa Olana \\ Lecturer, Wollega University, Ethiopia, Nekemte
}

\begin{abstract}
The effect of COVID-19 crisis on economy is due to public health measures to flatten the epi-curve. Even though, the crisis affects all economic sectors, the economic fallout from COVID-19 pandemics is particularly is acute in specific sectors such as SMEs. Studies indicate that SMEs may experience supply chain distortions due to irregular supply of raw materials and intermediate goods, revenue loss and shortage of liquidity to continue business operations. And also enterprises experienced a reduction in production / work activity/ contracts due to corona virus outbreak.
\end{abstract}

DOI: $10.7176 /$ RHSS/10-11-01

Publication date:June 30th 2020

\section{INTRODUCTION}

After the first infections in china at the end of 2019, the corona virus disease (COVID -19) has continued to spread across the world. It is declared as a pandemic by the World Health Organization (WHO) on May, 2020, COVID19 has become a global emergency, given its impact on the entire world population and the economy. As of today, according to world health organization (WHO) report update: May 31, 2020, the spread of the virus reached almost around 6 million in the world and around 1,067 in Ethiopian context.

Actions taken in response to the spread of COVID-19 have resulted in large scale disruption to business, with more volatile asset prices and currency exchange rates, and a marked decline in interest rates in the majority of economies around the World. The world is experiencing the closure of each business activities and stay at home principle by quitting different trading directions that can significantly which will eventually impact the world economy. Different literature evidences revealed that the COVID-19 had a significant impact on the financial system that directly affects the overall economy of the nation. The corona virus pandemic which has affected the global economy has also affected the African Economy through spillovers to African countries. Al most all, African countries have taken bold quarantine and lockdown measures to control the spread of COVID- 19 which comes as a cost such as a collapse of health system, education, business activities, economic crisis or recession, etc.

The world of work is being profoundly affected by the global virus pandemic. The crisis has already transformed into an economic and labor market shock, impacting all businesses regardless of their size. During this difficult time, it is important that jobs are preserved, enterprises remain sustainable, workers and their families affected are protected, in particular the most vulnerable, and those in the informal economy.

In Ethiopian context, after the entrance of corona virus in 13, March, 2020 many attentions are given to it how to defend the spread of the virus by the government and other concerned bodies. Hence, several industries and institutions reacted to the pandemic and a number of industries were affected from the COVID-19 shock. Apart from its health problem, an extensive increase of the disease and measures taken to control the spread in the poorer and food insecure countries could take a heavier toll on the economy and cause for economic slowdown. In general, lockdown and state of emergency in the country is expected to make the situation dire for all enterprises in the country. SMEs may experience supply chain distortions due to irregular supply of raw materials and intermediate goods, revenue loss and shortage of liquidity to continue business operations. Currently there are three million SMEs representing $99 \%$ of all enterprises throughout the country and employ around eleven million people, Gilberto M. Llanto (2010). Until 1980 the development plan of the government favored large scale firms or conglomerates and neglect SMEs. Therefore, this study intends to investigate the effect of COVID -19 on the small and medium enterprises in Ethiopia particularly addressing in Nekemte town.

\subsection{STATEMENT OF THE PROBLEM}

The corona virus (COVID-19) outbreak is causing a global health emergency, and a global economic slowdown. Trade, investment, growth, and employment are all affected and the crisis will have an impact on the achievement of the UN Sustainable Development Goals.

COVID-19 is shaking the world economy. The corona virus has already left dramatic rippling effects across the global economy, making a mark on the level of economic activity in every region of the world. In response to the virus, governments across the world have taken strict measures to curtail infection rates, to protect the functioning of healthcare systems and the most vulnerable members of society. The increasing spread of the corona virus across countries has prompted many governments to introduce unprecedented measures to contain the 
epidemic. These are priority measures that are imposed by a sanitary situation, which leave little room for other options as health should remain the primary concern. These measures have led to many businesses being shut down temporarily, widespread restrictions on travel and mobility, financial market turmoil, an erosion of confidence and heighted uncertainty.

In developing economies, SMEs make a significant contribution to local employment and to overall gross domestic product (GDP). An economic downturn due to COVID-19, to which SMEs are especially vulnerable, hits developing economies at the heart.

With generally small reserves and limited working capital, many SMEs rely upon a steady flow of continuous demand for their products and services. Many would struggle to survive a prolonged period of reduced economic activity. To prevent unemployment, poverty, and food insecurity rates from further skyrocketing, small and medium enterprises around the globe can and should play a crucial role especially in low-income and conflictaffected countries. Hence, this study intends to address the effect of corona virus on small and medium enterprises in Ethiopia.

\subsection{OBJECTIVES OF THE STUDY}

The general objective of this study is to assess the effect of Covid-19 in SMEs of Ethiopia, specifically in Nekemte Town.

\section{LITERATURE REVIEW}

According to the Economic Commission for Africa (ECA), Africa's cities are home to 600 million people and account for more than $50 \%$ of the region's GDP. This is even higher at more than $70 \%$ for countries such as Botswana, Uganda, Tunisia and Kenya. A third of national GPD (31\%) comes on average from the largest city in African countries. COVID-19 employment effects are likely to be severe in urban areas. With urban-based sectors of the economy (manufacturing and services) which currently account for 64\% of GDP in Africa, cities are expected to be hit hard by COVID-19 related effects, leading to substantial losses in productive jobs. And also the Economic Commission for Africa stated that" Firms and businesses in African cities are highly vulnerable to COVID-19 related effects, especially SMEs, which account for 80\% of employment in Africa".

Ruzvidzo explained that "Africa's cities drive consumption with their growing middle class with per capital consumption spending in large cities being on average 80 percent higher at the city level than at the national level. COVID-19 related decline in urban consumption will thus impact domestic value chains, including rural areas." Furthermore, with the per capital expenditure of African local authorities being the lowest in the world at 26 USD, many local authorities are poorly resourced and less able to contend with the onslaught of COVID-19. In the longer term, the acute vulnerability of city economies calls for efforts to revitalize and enhance the productivity of Africa's cities through adequate investments to address the substantial deficits and barriers they face.

\section{METHODOLOGY}

To assess the effect of COVID-19 on small and medium enterprises and its impact on businesses resilience, field survey and interview type of data collection method was employed on 40 respondents selected randomly from owners of SMEs from the total of SMEs operating in Nekemte City.

\section{FINDINGS/ ANALYSIS}

To analyze the respondent's response, a descriptive type of data analysis was performed and interpreted by using percentages.

\section{The MSME Sector in Ethiopia}

The micro, small and medium enterprise (MSME) sector has emerged as a highly vibrant and dynamic sector of the Ethiopian economy over the last decade. MSMEs not only play a crucial role in providing employment opportunities but also contribute enormously to the socio-economic development of the country, notably in their role as catalysts for the transition to an industrial society. MSMEs are viewed as seedbeds for the development of medium and large enterprises. It is reported that there are approximately more than 850,000 SMEs across the country.

In order to promote a broader, deeper engagement with MSMEs and help them fulfill their full economic potential, the government published its first national micro and small enterprises development strategy in 1997. The main objectives of the strategy were to promote economic growth, create sustainable jobs, strengthen collaboration among MSMEs and provide a platform for the transformation to medium and large enterprises. Driven by the conviction that MSMEs are key to laying the foundations for industrial development, the Ethiopian government placed them at the heart of successive poverty reduction and economic development plans in its GTP I and GTP II platforms.

The first GTP (Growth and Transformation Plan), prioritized MSME development and sought to scale up support. During GTP I, (2010- 2015), ETB 16.4 million was disbursed in loans to MSMEs and more than 7 million 
employment opportunities were created ( MoFEC, 2016).

The second growth and transformation plan (GTP II 2016- 2020) also continues to prioritize MSMEs but places greater emphasis on manufacturing, increased productivity and competitiveness. GTP II aims to disburse ETB 21 billion in loans to MSMEs through MFIs and stimulate the creation of 8.4 million jobs (MoFEC, 2008).

Now days in a contrary to the above, Ethiopia is facing the brunt of corona virus outbreak as the country is in a state of emergency. This has had a negative impact on a business. Initial estimates show that the economy will decline by $2.9 \%$

\section{DESCRIPTIVE ANALYSIS}

A survey conducted on 40 SME owners indicated that $75 \%$ of enterprises report their entire market (up to $100 \%$ ) to be local i.e. within the city. Only $25 \%$ of respondents sell their product / service nationally. (See: Table 1.1). As indicated on table $\mathbf{1 . 2}$ below, 95\% of enterprises experienced a reduction in production / work activity/ contracts due to corona virus outbreak. Only $5 \%$ respondents state that they have not experienced any reduction in their work activity by stating that they are providing services to door to door for their customers.

And also, $80 \%$ of respondents report that COVID-19 outbreak has affected up to $100 \%$ of their operations; whereas the left $20 \%$ of enterprises continued their operations with the challenges even though their income and customers is shown a dramatic decline after the corona virus outbreak especially after declaration of state of emergency in the country. (See Table 1.3)

The analysis show that; $90 \%$ of the enterprises reported a disruption in supply chain whereas $10 \%$ of enterprises reported that no disruption in supply chain because they find inputs easily from their local. (See: Table 1.4)

As indicated on Table 1.5 below, $45 \%$ of enterprises have laid off some of their employees due to lockdown while $55 \%$ report that they have not laid off any of their employees.

\section{FUTURE EXPECTATIONS OF THE ENTERPRISES AND THEIR ABILITY TO SUSTAIN DURING THE PANDEMIC.}

In wake of the corona virus pandemic, majority of enterprises $(60 \%)$ expect to continue with their present line of business over the next 1 year, while $12 \%$ say they would downsize their business. And also 18\% report that they may close down their business, while $10 \%$ would diversify into another line of business. (See: Table 1.6)

\section{POLICY IMPLICATIONS}

To overcome business resilience or to ameliorate their degree of impact on economic growth of the country and to SME owners, the following preconditions should be met as much as possible.

\# Entrepreneurs should take measures early to ensure their businesses have the resilience levels necessary to withstand an economic downturn or temporary closure.

* Special grants and interest free loans should be provided to SMEs by any financial institutions.

* Affected SMEs should be supported through an extended period of an economic downturn by increasing their liquidity -i.e. Efforts should be made to extend liquidity to Micro-Finance Institutes (MFIs) and to work with MFIs to in turn increase the availability of credit to small and affected businesses. This could take the form of tailored revolving loan funds established with MFIs to provide loans to affected SMEs to support them through the coming months. Funds will need to be channeled quickly to SMEs in need of support in fragile settings and SMEs should be supported in identifying and applying to appropriate funds.

* SME guidance center may be established in banks or in universities to provide a consultancy service for the victims of business resilience.

* A social safety net should be provided to persons made unemployed - Use of cash transfers to vulnerable and affected households to sustain them through the coming months until the economy has revived and employment is available.

* Efforts should be made to boost inclusive economic growth to limit the long-term impact of the pandemic

* Financial assistance may be provided to online businesses and financial schemes may be announced for services sector including IT businesses, business consultation, wholesale and retail, logistics, etc.

\# The government may provide tax considerations.

* Government may launch a special package for small and medium sized businesses to support investment.

\section{REFERENCES:}

\# Addis Fortune (Addis Ababa;By Maya Misikir; 17 APRIL 2020. 
* Africa Union (2020) IMPACT OF THE CORONAVIRUS (COVID 19) ON THE AFRICAN ECONOMY:https://www.google.com/search?client=firefox-b $\mathrm{d} \& \mathrm{q}=\mathrm{IMPACT}+\mathrm{OF}+\mathrm{THE}+\mathrm{CORONAVIRUS}+\% 28 \mathrm{COVID}+19 \% 29+\mathrm{ON}+\mathrm{THE}+\mathrm{AFRICAN}+\mathrm{ECONOM}$ Y

* Danish Refugee Council et al. (2020), The ripple effect of COVID-19 on economic activities, livelihoods and food security in East Africa and the Great Lakes

* El-Erian, M. (2020). The coming coronavirus recession and the uncharted territory beyond.https://www.foreignaffairs.com/articles/2020-03-17/coming-coronavirus recession.

* ILO (18 march 2020) covid-19 and the world of work: impact and policy responses

* NDRMC - ETHIOPIA: COVID-19 Humanitarian impact Situation Update No. 2, As of 13 April: https://www.google.com/search? client $=$ firefox $-b-d \& q=E T H I O P I A \% 3 A+C O V I D-$

$19+$ Humanitarian +impact + Situation + Update + No. $+2 \% 2 C+A s+o f+13+$ April

* Small and medium enterprises development authority, Pakistan; https:// www.researchgate.net/publication/340849874

* UNCTAD (2020), Special edition, counting the economic costs of corona virus, 12 March 2020, Geneva (Switzerland).

* UNDP (2020). The Social and Economic Impact of COVID-19 in the Asia-Pacific Region. Position Note prepared by UNDP Regional Bureau for Asia and the Pacific. Bangkok: United Nations Development Programme

* UNECA (2020), Economic Impact of the Covid-19 on Africa, Economic Commission for Africa, Addis Ababa, Ethiopia.

* UNICEF Ethiopia (2020), Socio-economic impacts of COVID-19, Update - 14th May 2020

* Warwick McKibbin and Roshen Fernando (2020). The Global Macroeconomic Impacts of COVID 19: Seven Scenarios- Working paper https://www.google.com/search?client=firefox-b$\mathrm{d} \& \mathrm{q}=\mathrm{The}+\mathrm{Global}+$ Macroeconomic+Impacts + of + COVID $+19 \% 3 \mathrm{~A}+$ Seven + Scenarios-+Working + paper .

* WHO https://www.who.int/emergencies/diseases/novel-corona virus-219 accessed on 11 March, 2020.

\section{APPENDIX}

Table 1:1 where do enterprises sell their product

\begin{tabular}{|l|c|l|}
\hline Description & Number of respondents & Percentages \\
\hline Locally & 30 & $75 \%$ \\
\hline Nationally & 10 & $25 \%$ \\
\hline Total & 40 & 100 \\
\hline
\end{tabular}

Table 1:2 Reductions in production/ Work activity/ contracts due to corona virus outbreak

\begin{tabular}{|l|c|l|}
\hline Description & Number of respondents & Percentages \\
\hline $\begin{array}{l}\text { Experienced a reduction in work } \\
\text { activity }\end{array}$ & 38 & $95 \%$ \\
\hline $\begin{array}{l}\text { Not experienced any reduction in } \\
\text { work activity }\end{array}$ & 2 & $5 \%$ \\
\hline \multicolumn{1}{|c|}{ Total } & 40 & 100 \\
\hline
\end{tabular}

Table 1:3 Orders / Work activity of SMEs Affected

\begin{tabular}{|c|c|c|}
\hline Description & Number of respondents & Percentages \\
\hline Orders/ work activity affected & 32 & $80 \%$ \\
\hline Orders /work activity not affected & 8 & $20 \%$ \\
\hline Total & 40 & 100 \\
\hline
\end{tabular}

Table 1:4 Disruptions in Supply Chain due to Corona Virus Outbreak

\begin{tabular}{|c|c|c|}
\hline Description & Number of respondents & Percentages \\
\hline Disruption in supply chain & 36 & $90 \%$ \\
\hline No disruption in supply chain & 4 & $10 \%$ \\
\hline Total & 40 & 100 \\
\hline
\end{tabular}


Table 1:5\% of Enterprises who have laid off employees

\begin{tabular}{|l|c|c|}
\hline Description & Number of respondents & Percentages \\
\hline Have laid off employees & 18 & $45 \%$ \\
\hline Have not laid off employees & 22 & $55 \%$ \\
\hline Total & 40 & 100 \\
\hline
\end{tabular}

Table 1:6 Future Expectations of Enterprises and their ability to sustain during lock down

\begin{tabular}{|l|c|l|}
\hline Description & Number of respondents & Percentages \\
\hline $\begin{array}{l}\text { Continue with present business } \\
\text { businersify into another line of }\end{array}$ & 24 & $60 \%$ \\
\hline Expand business & 4 & $12 \%$ \\
\hline Close down business & 7 & $10 \%$ \\
\hline Total & 40 & $18 \%$ \\
\hline
\end{tabular}

